\title{
Immobilization of Bacillus megaterium MTCC 2444 by Ca- alginate Entrapment Method for Enhanced Alkaline Protease Production
}

\author{
Soma Mrudula* and Nidhi Shyam \\ Department of Microbiology; M. G. R. College; Dr. M. G. R. Nagar; Hosur-635109; Tamil Nadu - India
}

\begin{abstract}
Optimization of culture conditions and immobilization parameters for alkaline protease production was carried out by employing Bacillus megaterium MTCC2444. The partially purified enzyme was tested for its stability in the presence of oxidants, surfactants and commercial detergents. The optimum temperature, pH, incubation time and inoculum size were $55^{\circ} \mathrm{C}, 11,48 \mathrm{~h}, 1 \%$, respectively. Calcium alginate was used as the immobilization matrix and the effects of gel concentration, bead size, age of immobilized cells, solidification period and initial biomass concentration on alkaline protease production and cell leakage were investigated. The results indicated that the immobilization was most effective with $4 \%$ gel concentration, bead size of $3 \mathrm{~mm}, 24$ h aged immobilized cells for a solidification period of $12 \mathrm{~h}$ at $1.5 \%$ initial biomass concentration. The enzyme showed good stability in the presence of oxidants, surfactants and commercial detergents.
\end{abstract}

Key words: optimization, immobilized cells, cell leakage, detergent, oxidant stability

\section{INTRODUCTION}

Proteases are among the commercially most viable enzymes which constitute about $65 \%$ of the total industrial enzyme market (Oskouie et al. 2008). They find multiple applications in the industrial sectors such as food, pharmaceutical, leather and detergent (Gupta et al. 2002). Proteases are classified as acidic, neutral or alkaline depending on their activity at different $\mathrm{pH}$ (Al-Shehri et al. 2004). Today, the largest share of the enzyme market has been held by the detergent alkaline proteases that are active at alkaline $\mathrm{pH}$ range. The feasibility of protease application in the detergents depends on its compatibility and stability with all commonly used detergent components such as surfactants and oxidizing agents (Cheng et al. 2010).
Microorganisms are the predominant producers of the proteases, among which Bacillus sp. has been commercialized for alkaline protease production (Abo-Aba et al. 2006). Microbial enzymes are usually obtained from free or immobilized cells. Whole cell immobilization technique has several advantages over free cell systems such as higher yield of enzyme activity, higher operational stability, greater resistance to environmental perturbations, lower enzyme cost and repeated use of biocatalyst (Mamo and Gessesse 2000; Nampoothiri et al. 2005; Konsoula and Liakopoulou 2006). The most common immobilization matrix used nowadays is alginate, since encapsulation in Ca-alginate gels occurs under very mild conditions and is characterized by the low cost (Bladino et al. 2001; Dey et al. 2003).

*Author for correspondence: somamrudula@hotmail.com 
The present work focused on the screening of $B$. megaterium MTCC2444 for alkaline protease production. The optimization of physical and immobilization parameters for enhanced production of alkaline protease was carried out. Further the enzyme was tested for its possible application as a detergent additive.

\section{MATERIALS AND METHODS}

\section{Microorganism and culture maintenance}

The microorganism used in this study was Bacillus megaterium MTCC2444 supplied from Microbial Type Culture Collection (MTCC) and Gene Bank, Institute of Microbial Technology, Chandigarh, India. The strain was maintained at $4{ }^{\circ} \mathrm{C}$ on nutrient agar slants and was sub-cultured fortnightly.

\section{Screening of Bacillus megaterium MTCC 2444 for enzyme production}

The strain was plated on skim milk agar medium (Norazizah et al. 2005). The inoculated plates were then incubated at $35{ }^{\circ} \mathrm{C}$ for $48 \mathrm{~h}$. After this, the plates were flooded with $\mathrm{HgCl}_{2}-\mathrm{HCl}$ solution for 5 min. The organism was screened for the production of alkaline protease by growing at $\mathrm{pH}$ 10.0 .

\section{Cultivation of $B$. megaterium}

The strain was grown in $250 \mathrm{ml}$ Erlenmeyer flasks containing $25 \mathrm{ml}$ of culture medium at $55{ }^{\circ} \mathrm{C}$ for $48 \mathrm{~h}$. The culture medium used for growing the strain contained $(\mathrm{g} / \mathrm{l})$ in distilled water $(\mathrm{pH} 7.0)$ : Casein, 10.0; glucose, 10; yeast extract, 3; peptone, 5; $\mathrm{NaCl}, 5 ; \mathrm{CaCl}_{2} .2 \mathrm{H}_{2} \mathrm{O}, 0.4$ and $\mathrm{MgCl}_{2}$, 0.2 .

\section{Enzyme extraction}

At the end of the fermentation, the broth was centrifuged at 6000 relative centrifugal force (RCF) for $20 \mathrm{~min}$ at $4{ }^{\circ} \mathrm{C}$ and the cell free supernatant obtained was used as the source of extracellular enzyme.

\section{Enzyme activity}

Enzyme extract $(1.0 \mathrm{~mL})$ was mixed with $1.0 \mathrm{~mL}$ of casein solution $(1 \%$, w/v) prepared in glycine$\mathrm{NaOH}$ buffer $(0.1 \mathrm{M}, \mathrm{pH} 10.0)$ and incubated at $50{ }^{\circ} \mathrm{C}$ for $30 \mathrm{~min}$. After incubation, the reaction was terminated by the addition of $5.0 \mathrm{ml}$ of trichloroacetic acid (TCA) (5\%, v/v) and was further allowed to stand for $10 \mathrm{~min}$ to precipitate the undigested protein. The contents were then centrifuged at $10,000 \mathrm{RCF}$ for $10 \mathrm{~min}$. The amount of amino acids released was estimated using a standard curve of tyrosine (Lowry et al. 1951). A suitable control (prepared by adding TCA to the substrate prior to the addition of the enzyme) was run simultaneously.

One unit of protease is defined as that amount of enzyme that releases $1 \mu \mathrm{g}$ of tyrosine per minute under specific conditions of assay.

\section{Optimization of physical parameters}

The parameters selected for the optimization were temperature $\left(25-60{ }^{\circ} \mathrm{C}\right), \mathrm{pH}$ (4.0-13.0), incubation period (24-96 h) and inoculum size (0.5-3\%).

\section{Cell immobilization}

Wet cells were prepared by growing the organism in $250 \mathrm{ml}$ Erlenmeyer flasks containing $100 \mathrm{ml}$ culture medium at $55{ }^{\circ} \mathrm{C}$ for $48 \mathrm{~h}$. After fermentation, the cells were harvested by centrifuging the broth at $6000 \mathrm{RCF}$ for $20 \mathrm{~min}$ at 4 ${ }^{\circ} \mathrm{C}$. The cells were then washed thrice with sterile saline and re-centrifuged. The washed cells were used with same concentration for the immobilization and in experiments with the free cells. The entrapment of cells in calcium alginate beads was carried out by extruding through a syringe a mixture of alginate slurry $(3 \%, \mathrm{w} / \mathrm{v})$ and wet weight $(0.6 \% \mathrm{w} / \mathrm{v})$ into a gently stirred $0.2 \mathrm{M}$ $\mathrm{CaCl}_{2}$ solution at room temperature. The beads formed were kept for curing at $4{ }^{\circ} \mathrm{C}$ for $1 \mathrm{~h}$. The cured beads were washed with sterile distilled water for three to four times and was then subjected to fermentation.

\section{Fermentation}

The immobilized cells were added to $250 \mathrm{ml}$ Erlenmeyer flasks containing $50 \mathrm{ml}$ of production medium. The composition of the production medium was same as that of growth medium, except the difference in the concentration of $\mathrm{CaCl}_{2}$ added. In the production medium $0.5 \mathrm{~g} / \mathrm{l}$ of $\mathrm{CaCl}_{2}$ was added in order to keep the beads intact during the prolonged operation. Batch fermentations with free and immobilized cells were carried out by incubating the flasks at $55^{\circ} \mathrm{C}$ for $120 \mathrm{~h}$. The samples were withdrawn at regular intervals of 24 $\mathrm{h}$ and assayed for cell leakage and alkaline protease activity. The effectiveness factor of the immobilized system was defined as the ratio of alkaline protease activity of the the immobilized 
systems to that of the free cells (Anisha and Prema 2008).

\section{Cell growth and cell leakage}

The cell growth in freely suspended cultures and cells leaked from the gel matrix were determined as cell wet weight $(\mathrm{CWW})$ by measuring the optical density at $660 \mathrm{~nm}$. The optical density value was then converted into $\mathrm{mg} \mathrm{CWW} / \mathrm{l}$ using a standard curve (Reyed 2007).

\section{Optimization of bead characteristics}

For the preparation of the beads with proper permeability and rigidity, the following parameters were optimized: gel concentration (2, 4 and $6 \%$ ), bead size $(3,5$ and $7 \mathrm{~mm})$, initial biomass concentration (0.3-2.0\%), solidification period (3, 12 and $24 \mathrm{~h}$ ) and age of immobilized cells (24, 48 and $72 \mathrm{~h}$ ). The fermentation was carried out at $55^{\circ} \mathrm{C}$ for $72 \mathrm{~h}$.

\section{Repeated batch fermentation}

Optimized conditions of immobilization (gel concentration, $4 \%$; bead diameter, $5 \mathrm{~mm}$; biomass concentration, $1.5 \%$; age on immobilized cells, 24 $\mathrm{h}$ and solidification time, $24 \mathrm{~h}$ ) were selected for effective cell encapsulation in repeated batch fermentation. After attaining the maximum production of alkaline protease $(72 \mathrm{~h})$, the beads collected from the spent medium were washed with sterile saline solution and transferred aseptically to fresh production medium $(50 \mathrm{ml})$. The process was repeated for ten cycles until the beads started disintegrating. The enzyme titres and cell leakage of each cycle were determined. The operational stability of the immobilized system was determined by the standard procedures reported in literature (Konsoula and Liakopoulou 2006; Anisha and Prema 2008).

\section{Partial purification by precipitation and dialysis}

Enzyme in the cell free supernatant portion of the culture was precipitated by ammonium sulphate upto $80 \%$ saturation and kept overnight at $4{ }^{\circ} \mathrm{C}$ (Venugopal and Saramma 2006). The precipitate was recovered by centrifugation at $6000 \mathrm{RCF}$ for $10 \mathrm{~min}$ and re-suspended in $0.1 \mathrm{M}$ glycine- $\mathrm{NaOH}$ buffer of pH 10.0 (Qader et al. 2009). This was dialyzed against the same buffer. The dialyzed fraction was centrifuged at $6000 \mathrm{RCF}$ for $10 \mathrm{~min}$ and the alkaline protease activity was tested in the supernatant. The purified extract was further used for applications in the detergents.

\section{Detergent application}

The protease $(0.5 \mathrm{U} / \mathrm{ml})$ was incubated with varying concentrations of oxidizing agent such as $\mathrm{H}_{2} \mathrm{O}_{2}$ (1 to $5 \%$ ), surfactants such as SDS $(0.05$, $0.1,0.2,0.4$ and $0.6 \%)$ and Triton X-100 (0.1, 0.4, $0.7,1$ and $4 \%$ ) for $30 \mathrm{~min}$. The residual activity was measured by standard assay procedure. The stability of the protease in the commercial detergents were tested by incubating the enzyme $(0.5 \mathrm{U} / \mathrm{ml})$ with the solutions of different commercial detergents such as Ariel, Tide, Henko, Surf excel and Wheel at a concentration of 7 $\mathrm{mg} / \mathrm{ml}$ for $1 \mathrm{~h}$. Suitable aliquots were withdrawn at different time intervals and the residual activities were measured by the standard assay procedure. It was compared with the control incubated under similar conditions without any detergent. Also, to rule out the possibility of any protease (if at all present) contained as ingredient of the detergent, the detergent solutions at a concentration of $7 \mathrm{mg} / \mathrm{ml}$ were assayed for alkaline protease activity without incubating with the enzyme.

\section{RESULTS AND DISCUSSION}

The strain MTCC2444 produced transparent circular zones around the colonies in an opaque white background detected protease production. Initially, the strain produced $471 \mathrm{U} / 1$ enzyme at $55{ }^{\circ} \mathrm{C}$ for $48 \mathrm{~h}$.The enzyme production was maximum at $55^{\circ} \mathrm{C}$ (Fig. 1). Some authors have reported optimum temperature as $50{ }^{\circ} \mathrm{C}$ (Shaheen et al. 2008; Boominadhan et al. 2009). On the other hand, $37{ }^{\circ} \mathrm{C}$ has been reported as the optimum temperature for protease production by B. proteolyticus CFR3001, B.pumilus SG2 and Bacillus sp. (Bhaskar et al. 2007; Sangeetha et al. 2008; Nagalakshmi and Ramesh 2009). It has been noted that the important characteristic of most microorganisms is their strong dependence on the extracellular $\mathrm{pH}$ for cell growth and enzyme production (Kumar and Tagaki 1999).

The results of $\mathrm{pH}$ studies showed that the strain MTCC2444 produced maximum yield at $\mathrm{pH} 11.0$ (Fig. 2). Similar results were reported for the protease production by $B$. subtilis BS1 (Shaheen et al. 2008), whereas the optimum $\mathrm{pH}$ of 9.0 and 10.5 were recorded for B. cereus MTCC6840 and B. circulans, respectively (Joshi et al. 2007; 
Jaswal et al. 2008). The optimum incubation time was $48 \mathrm{~h}$ (Fig. 3). This was in agreement with the findings of Shumi et al. (2004) for protease production by Listeria monocytogenes. In contrast,
36 and $40 \mathrm{~h}$ of incubation time was found maximum for protease production by $B$. pumilus SG2 (Sangeetha et al. 2008) and B. circulans (Jaswal et al. 2008), respectively.

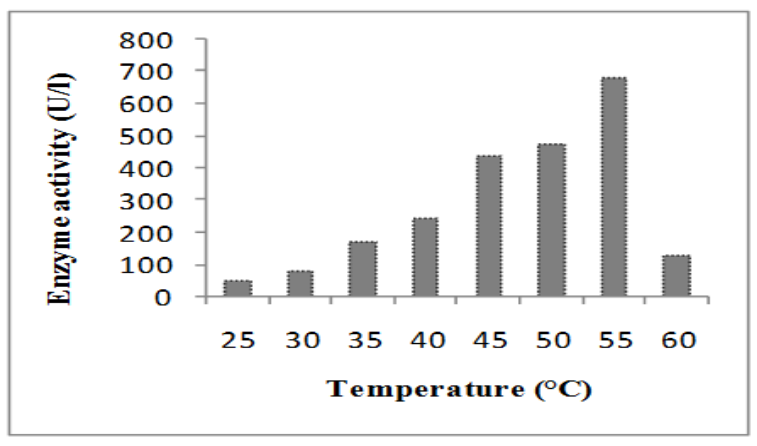

Figure 1 - Effect of temperature on alkaline protease production by B. megaterium MTCC 2444.

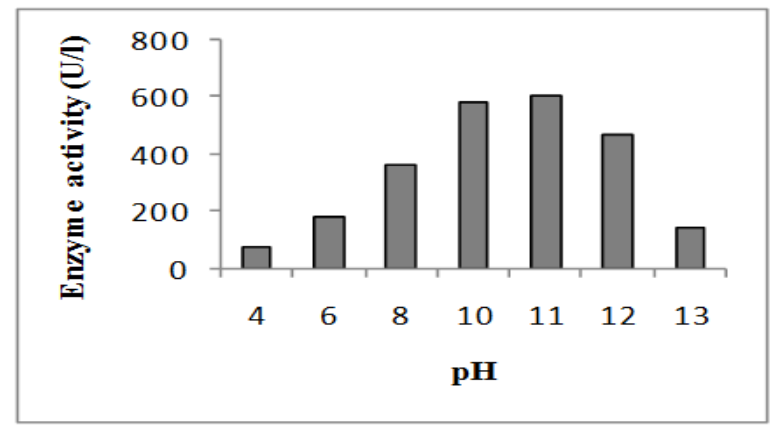

Figure 2- Effect of pH on alkaline protease production by B. megaterium MTCC 2444.

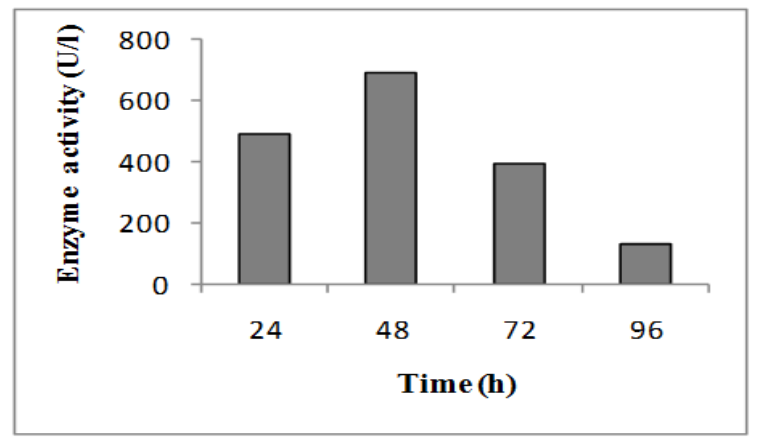

Figure 3 - Effect of incubation period on alkaline protease production by $B$. megaterium MTCC 2444.

The enzyme yield of B. megaterium MTCC2444, reached maximum at $1 \%$ inoculum size (Fig. 4). These results were comparable with that of Nagalakshmi and Ramesh (2009) for alkaline protease production by Bacillus sp. Under these conditions, the strain MTCC2444 produced 699 U/l enzyme.
The observations of the present experiment revealed that there was 1.5 -fold increase in the enzyme yield by the immobilized cells when compared to free cells. The production of $\alpha$ galactosidase by Streptomyces griseoloalbus showed that there was a 2-fold increase in the enzyme yield by the immobilized cells than that of 
free cells (Anisha and Prema 2008). The study showed higher production of protease because the immobilized cell displayed better operational stability (Fortin and Vuillemard 1990; Kukubu et al. 1981), higher efficiency of catalysis
(Ramakrishna et al. 1992). They are reusable (Mamo and Gessesse 2000) and greater resistance to environmental perturbations (Konsoula and Liakopoulou 2006).

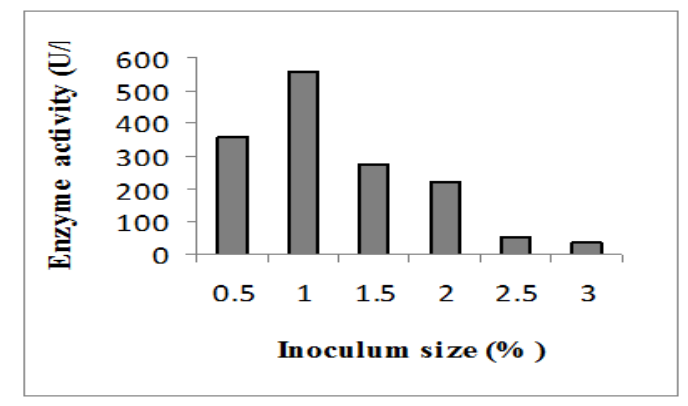

Figure 4 - Effect of inoculum size on alkaline protease production by B. megaterium MTCC 2444.

Gel concentration has a significant effect on the enzyme production. The optimum concentration of alginate may differ with respect to the organism and the product of interest (Nampoothiri and Pandey 1998). In order to elucidate the effect of alginate used for the entrapment of B. megaterium, three different sodium alginate concentrations were tried. The production of alkaline protease was maximum with $4 \%$ alginate as compared to other concentrations used (Fig. 5). These results were in agreement with the investigations of Shinmyo et al. (1982) and Dobreva et al. (1996) for the production of $\alpha$-amylase by $B$. amyloliquefaciens and $B$. licheniformis, respectively. It has been reported that $2 \%$ of gel concentration showed maximum production of lactic acid from pineapple waste using immobilized Lactobacillus delbrueckii (Idris and Suzana 2006). It has been shown that at higher gel concentration, the enzyme yields decreased due to poor diffusion of nutrients through the beads. However when $2 \%$ gel concentration was used, the beads produced were too soft and fragile, resulting in cell leakage from the beads.

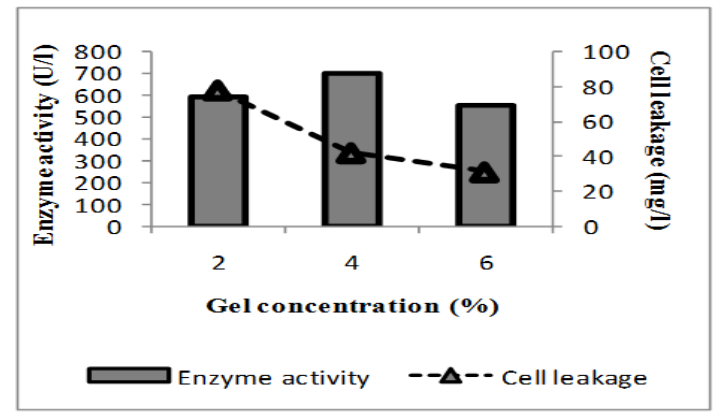

Figure 5 - Effect of gel concentration on cell leakage and alkaline protease production by $B$. megaterium MTCC 2444.

The maximum alkaline protease yields was attained for $3 \mathrm{~mm}$ bead diameter by the strain MTCC2444. A further increase in bead diameter beyond this value did not improve the enzyme production (Fig. 6). Smaller bead diameter produced higher protease production. This could be due to an increase in the surface volume ratio
(Guoqiang et al. 1991; El-Katany et al. 2003). Similar pattern was also reported by Idris and Suzana (2006) for lactic acid production at $1 \mathrm{~mm}$ bead size for higher yield. An optimum bead diameter of $5.2 \mathrm{~mm}$ have been reported for alkaline protease production (Kocher and Mishra 2009). 
In the present, study the optimum initial biomass was $1.5 \%$ (Fig. 7). As the biomass concentration in the gel beads increased, the cell leakage into the fermentation medium also increased correspondingly. This could be attributed to the fact that when the cell loading in the beads increased, the nutrient/cell ratio decreased, which might become limiting (Beshay 2003). These results seemed to be in agreement with work performed by Anisha and Prema (2008) for $\alpha$ galactosidase by $S$.griseoloalbus. Dobreva et al. (1996), working with immobilized B. licheniformis found that an optimum biomass concentration of $0.4 \%$ for $\alpha$-amylase production.

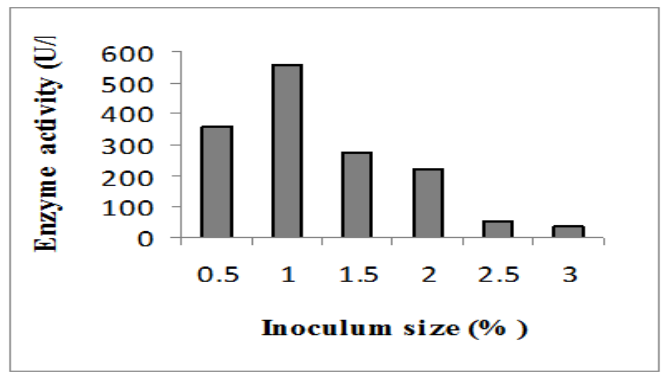

Figure 6 - Effect of bead diameter on cell leakage and alkaline protease production by $B$. megaterium MTCC 2444.

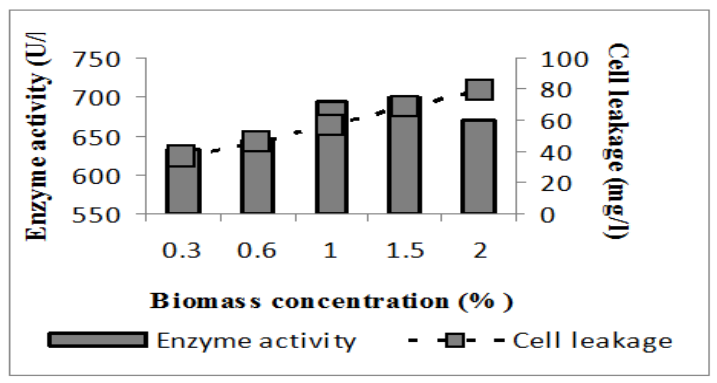

Figure 7 - Effect of biomass concentration on cell leakage and alkaline protease production by $B$. $b$ megaterium MTCC 2444.

Prolongation of solidification time improves the stability of beads. The optimum solidification time for the maximum protease production by $B$. megaterium MTCC2444 was $12 \mathrm{~h}$ with subsequent decrease in cell leakage (Fig. 8). In contrast, the solidification time of $24 \mathrm{~h}, 1 \mathrm{~h}$ and $10 \mathrm{~h}$ improved the stabilities of gel beads entrapped with $B$. licheniformis (Dobreva et al. 1996), A. niger
(Ellaiah et al. 2004) and S. griseoloalbus (Anisha and Prema 2008) for the production of $\alpha$-amylase, lipase and $\alpha$-galactosidase, respectively.Results for the different ages of beads showed that $24 \mathrm{~h}$ yielded maximum when compared with other aged beads (Fig. 9). Dobreva et al. (1996) found $36 \mathrm{~h}$ aged beads best for $\alpha$-amylase production.

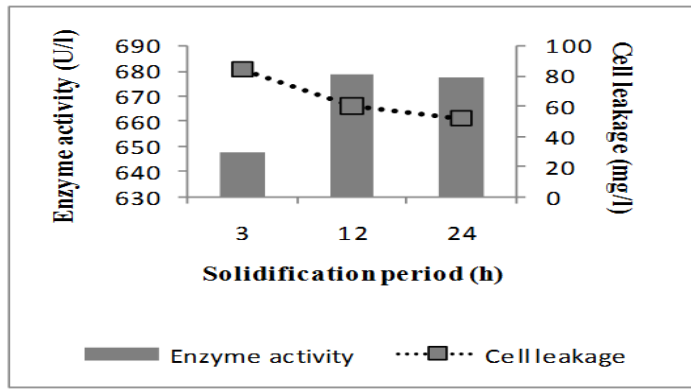

Figure 8 - Effect of solidification period on stability of gel beads, alkaline protease production and cell leakage by $B$. megaterium MTCC 2444. 


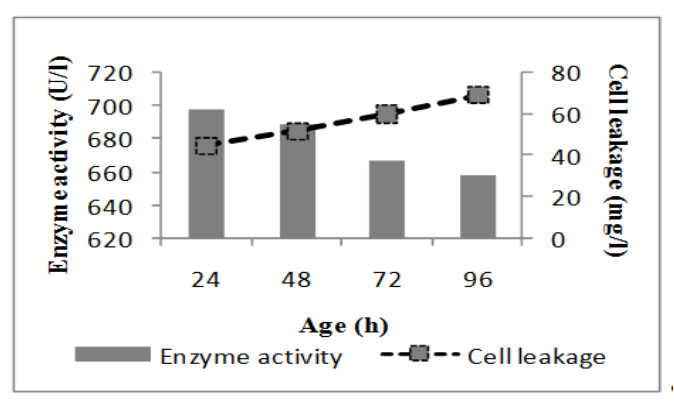

Figure 9 - Effect of age of immobilized cells on cell leakage and alkaline protease production by B. megaterium MTCC2444.

Whole cell immobilization of alkaline protease offered the advantage of using the immobilized cells in repeated batch fermentation processes. Gel concentration, bead diameter, biomass concentration, solidification time and age of immobilized cells are highly dependent on the operational stability and efficiency of the immobilized cells. The optimum conditions selected for the effective immobilization of $B$ megaterium MTCC 2444 were $4 \%$ gel concentration, $3 \mathrm{~mm}$ bead diameter, $1.5 \%$ biomass concentration, solidification time of $12 \mathrm{~h}$ and $24 \mathrm{~h}$ aged immobilized cells. Under these conditions, alginate beads retained upto $95 \%$ of their operational efficiency upto three successive fermentation cycles and beads retained $50 \%$ ability of enzyme production upto eight cycles of fermentation (Fig. 10). The immobilized beads of $S$. griseoloalbus for $\alpha$-galactosidase production could be reused efficiently without any loss of enzyme upto three cycles and beads had good stability and retained $75 \%$ ability of enzyme production after eight cycles of repeated batch fermentation (Anisha and Prema 2008).

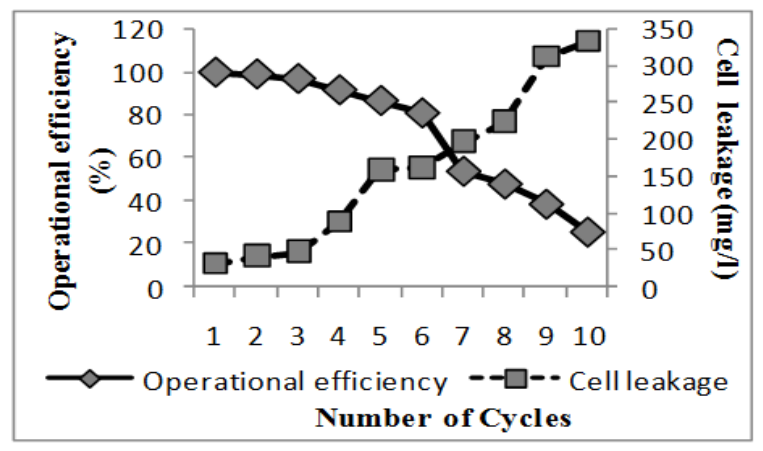

Figure10 - Operational stability of immobilized cells.

The enzyme showing stability towards the oxidizing agents are more promising in detergent industries as peroxides are common ingredients of modern bleach-based detergent formulations. In the present study, $\mathrm{H}_{2} \mathrm{O}_{2}$ at a concentration of $1 \%$ showed $100 \%$ residual activity. Whereas at $5 \%$ concentration, there was $168 \%$ increase in the residual activity (Fig.11). Previous reports on the stability of alkaline protease indicated that $B$. clausii I-52 protease exhibited residual activity upto $114 \%$ after the treatment with $1 \% \mathrm{H}_{2} \mathrm{O}_{2}$ (Joo et al. 2003). While an alkaline protease from
Vibrio fluvialis VM10 strain showed $132 \%$ $\begin{array}{llllll}\text { activity after incubation with } & 4 & \% & \mathrm{H}_{2} \mathrm{O}_{2}\end{array}$ (Venugopal and Saramma 2006).

A good detergent protease should have ability to work in the presence of surfactant active agents. The treatment with SDS in the concentration range of 0.05 to $0.6 \%$ retained the protease activity from B. megaterium MTCC 2444 in the range of 70 to $75 \%$ (Fig.12). These results were similar to the activity of protease of $B$. cereus MTCC6840 at 1 $\%$ concentration of SDS (Joshi et al. 2007). In contrast, VM10 protease showed 60 to $65 \%$ 
activity towards 0.05 to $0.4 \%$ SDS concentration (Venugopal and Saramma 2008). The results obtained in this study revealed that the enzyme was slightly inactivated and retained the activity in the range of 60 to $82 \%$ at a concentration of 0.1 to $4 \%$ Triton X-100 (Fig.13). Similar results were observed for VM10 protease (Venugopal and Saramma 2006).

Among the various detergents tested in the present study, the maximum stability was obtained for Surf excel (46\%) after $1 \mathrm{~h}$ of incubation (Fig. 14). Similar results were obtained for VM10 protease with Surf retaining activity of $61 \%$ (Venugopal and Saramma 2006). The studies on alkaline protease production by Bacillus sp. APR-4 on detergent stability showed that Fena and Farishta detergents retained stability of $78 \%$ upto $24 \mathrm{~h}$ of incubation (Kumar and Bhalla 2004).

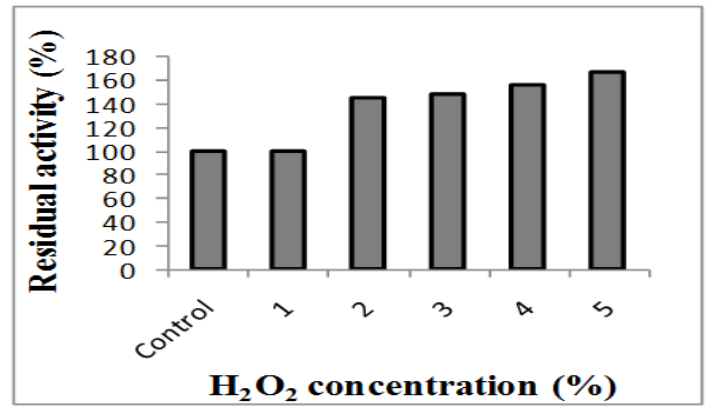

Figure 11 - Stability of the alkaline protease in oxidants.

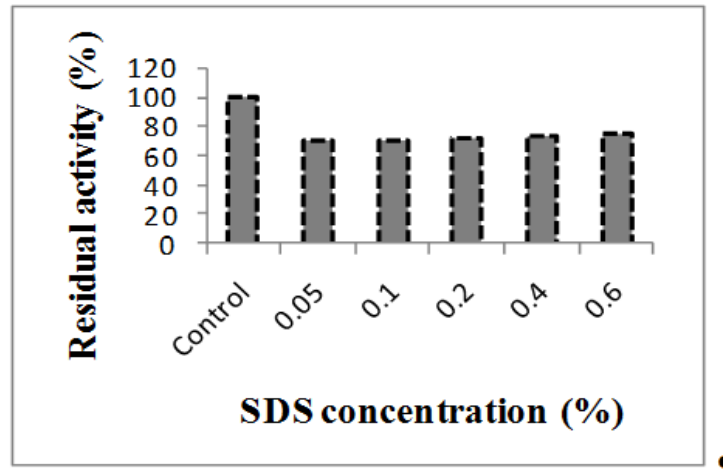

Figure 12 - Stability of alkaline protease in SDS.

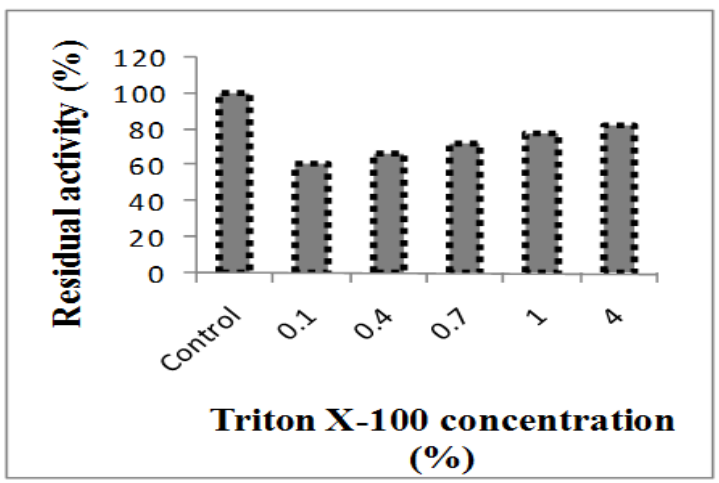

Figure 13 - Stability of alkaline protease in Triton X- 100. 


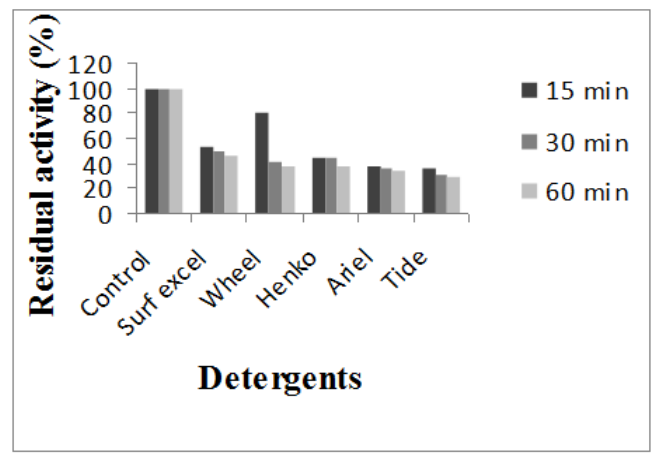

Figure 14 - Stability of alkaline protease in commercial detergents.

\section{CONCLUSION}

In the present study, the optimization of physical conditions and cell immobilization for alkaline protease production by $B$. megaterium was carried out. Under the optimum conditions, the enzyme yields were higher. Sodium alginate served as a good matrix for the entrapment of $B$. megaterium cells for alkaline protease production. In addition, the enzyme was much promising with regard to stability in the oxidants, surfactants and commercial detergents. These properties could make this protease as an ideal choice for application in the detergent formulations.

\section{ACKNOWLEDGEMENT}

The authors wish to acknowledge the Management, M.G.R.College, Hosur for providing laboratory facilities.

\section{REFERENCES}

Abo-Aba SEM, Soliman EAM, Nivien AA. Enhanced production of extracellular alkaline protease in Bacillus circulans through plasmid transfer. Res $J$ Agr Biol Sci. 2006; 2: 526-530.

Al-Shehri LM, Abdul-Rahman M, Yasser S. Production and some properties of protease produced by Bacillus licheniformis isolated from Tihamet Aseer, Saudi Arabia. Pak J Biol Sci. 2004; 7: 1631-1635.
Anisha GS, Prema P. Cell immobilization technique for the enhanced production of $\alpha$-galactosidase by Streptomyces griseoloalbus. Bioresour Technol. 2008; 99: 3325-3330.

Beshay U. Production of alkaline protease by Teredinobacter turnirae cells immobilized in Caalginate beads. Afr J. 2003; 2: 60-65.

Bhaskar N, Sudeepa ES, Rashmi HN, Tamil Selvi A. Partial purification and characterization of protease of Bacillus proteolyticus CFR 3001 isolated from fish processing waste and its antibacterial activities. Bioresour Technol. 2007; 98: 2758-2764.

Bladino A, Macias M, and Cantero D. Immobilization of glucose oxidase with calcium alginate gel capsules. Process Biochem. 2001; 36: 601-606.

Boominadhan U, Rajakumar R, Sivakumar PKV, Melvin MJ. Optimization of protease enzyme production using Bacillus sp. isolated from different wastes. Bot Res Intl. 2009; 2: 83-87.

Cheng K, Lu FP, Li M, Liu LL, Liang XM. Purification and biochemical characterization of a serine alkaline protease TC4 from a new isolated Bacillus alcalophilus TCCC11004 in detergent formulations. Af J Biotech. 2010; 9: 4942-4953.

Dey G, Singh B, Banerjee R. Immobilization of $\alpha$ amylase produced by Bacillus circulans GRS 313. Braz Arch Biol Technol. 2003; 46: 167-176.

Dobreva E, Ivanova V, Tonkova A, Radulova E. Influence of the immobilization conditions on the efficiency of $\alpha$-amylase production by Bacillus licheniformis. Process Biochem. 1996; 31: 229-234.

El-Katany MH, Ahmed MH, Gehan MS, El-Komy HM. Enzyme production by alginate encapsulated Trichoderma sp. Food Technol Biotech. 2003; 41: 219-225. 
Ellaiah P, Prabhakar T, Ramakrishna B, Thaer Taleb A, Adinarayana K. Production of lipase by immobilized cells of Aspergillus niger. Process Biochem. 2004; 39: 525-528.

Fortin C, Vuillemard JC. Culture fluorescence monitoring of immobilized cells. Physiology of Immobilized Cells. 1990; 34: 45-55.

Guoqiang D, Kaul R, Mattiasson B. Evaluation of alginate immobilized Lactobacillus casei for lactate production. Appl Microbiol Biot. 1991; 36: 309-314.

Gupta R, Beg QK, Khan S, Chauhan B. An overview on fermentation, downstream processing and properties of microbial alkaline proteases. Appl Microbiol Biot. 2002; 60: 381-395.

Idris A, Suzana W. Effect of sodium alginate concentration, bead diameter, initial $\mathrm{pH}$ and temperature on lactic acid production from pineapple waste using immobilized Lactobacillus delbrueckii. Process Biochem. 2006; 41: 1117-1123.

Jaswal RK, Kocher GS, Virk MS. Production of alkaline protease by Bacillus circulans using agricultural residues: a statistical approach. Indian $J$ Biotechnol. 2008; 7: 356-360.

Joo HS, Kumar CG, Park GC, Paik SR, Chang CS. Oxidant and SDS-stable alkaline protease from Bacillus clausii I-52: production and some properties. J Appl Microbiol. 2003; 95: 267-272.

Joshi GK, Kumar S, Sharma V. Production of moderately halotolerant, SDS-stable alkaline protease from Bacillus cereus MTCC 6840 isolated from lake Nainital, Uttaranchal state, India. Braz J Microbiol. 2007; 38: 773-779.

Kocher GS, Mishra S, Immobilization of Bacillus circulans MTCC 7906 for enhanced production of alkaline protease under batch and packed bed fermentation conditions. Internet J Microbiol. 2009; 7: 359-378.

Konsoula Z, Liakopoulou MK. Starch hydrolysis by the action of an entrapped in alginate capsules $\alpha$-amylase from Bacillus subtilis. Process Biochem. 2006; 41: 343-349.

Kukubu T, Karube I, Suzuki S. Protease production by immobilized mycelia of Streptomyces fradiae. Biotechnology and Bioengineering. 1981; 23: 29-37.

Kumar CG, Tagaki H. Microbial alkaline proteases: from a bioindustrial viewpoint. Biotech Adv. 1999; 17: 561-594.

Kumar D, Bhalla TC. Bacillus sp. APR-4 protease as a laundry additive. Indian J Biotechnol. 2004; 3: 563 567.

Lowry OH, Rosebrough NJ, Farr AL, Randall RJ. Protein measurement with the folin phenol reagent. Journal of Biological Chemistry. 1951; 193: 265-273.

Mamo G, Gessesse A. Immobilization of alkaliphilic Bacillus sp. Cells for xylanase production using batch and continuous culture. Appl Biochem Biotechnol. 2000; 87: 95-101.
Nagalakshmi R, Ramesh S. Studies on the production of protease by Bacillus sp. Recent Research in Science and Technology. 2009; 1: 250-254.

Nampoothiri KM, Pandey A. Immobilization of Brevibacterium cells for the production of L-glutamic acid. Bioresour Technol. 1998; 63: 101-106.

Nampoothiri KM, Roopesh K, Chacko S, Pandey A. Comparative study of amidase production by free and immobilized Escherichia coli cells. Appl Biochem Biotechnol. 2005; 120: 97-108.

Norazizah S, Sayangku N, Abd-Rahman RNZ, Basri M, Salleh AB. Optimization of environmental and nutritional conditions for the production of alkaline protease by a newly isolated bacterium Bacillus cereus strain 146. J Appl Sci Res. 2005; 1: 1-8.

Oskouie SFG, Tabandeh F, Yakhchali B, Eftekhar F, Response surface optimization of medium composition for alkaline protease production by Bacillus clausii. Biochem Eng J. 2008; 39: 37-42.

Qader SA, Iqbal S, Niazi Z. Partial purification and characterization of intracellular alkaline phosphatase from newly isolated strain of Bacillus subtilis KIBGE-HAS. Internet J Microbiol. 2009; 7: 401-404.

Ramakrishna SV, Jamuna R, Emery AN. Production of ethanol by immobilized yeast cells. Appl Biochem Biotechnol. 1992; 37: 275-282.

Reyed MR. Biosynthesis and properties of extracellular amylase by encapsulation of Bifidobacterium bifidum in batch culture. Aust J Basic Appl Sci. 2007; 1: 7-14. Sangeetha R, Geetha A, Arulpandi I. Optimization of protease and lipase production by Bacillus pumilus SG2 isolated from an industrial effluent. Internet $J$ Microbiol. 2008; 5: 1-9.

Shaheen M, Aamer AS, Abdul H, Fariha H. Influence of culture conditions on production and activity of protease from Bacillus subtilis BS1. Pak J Bot. 2008; 40: 2161-2169.

Shinmyo A, Kimura H, Okada H. Physiology of $\alpha-$ amylase production by immobilized Bacillus amyloliquefaciens. Eur J Appl Microbiol Biotechnol. 1982; 14: 7-12.

Shumi W, Towhid Hossain MD, Anwar MN. Production of protease from Listeria monocytogenes. Int J Agr Biol. 2004; 6: 1097-1100.

Venugopal M, Saramma AV. Characterization of alkaline protease from Vibrio fluvialis strain VM10 isolated from a mangrove sediment sample and its application as a laundry detergent additive. Process Biochem. 2006; 41: 1239-1243.

Received: Julho 28, 2010; Revised: January 02, 2011; Accepted: November 23, 2011. 